East African Medical Journal Vol. 81 No. 4 April 2004

HEPATITIS C VIRUS SEROPREVALENCE AMONG MOTHERS DELIVERING AT THE KORLE-BU TEACHING HOSPITAL, GHANA

A.T. Lassey, FRCOG, FWACS, Senior Lecturer, N. K. Damale, MBChB, MRCOG, Lecturer, Department of Obstetrics and Gynaecology, V. Bekoe, BSc., Senior Laboratory Technologist, Public Health Reference Laboratory, and C. A Klufio, FRCSE, FRCOG, FWACS, Associate Professor, Department of Obstetrics and Gynaecology, University of Ghana, Medical School, P. O. Box GP 4236, Accra, Ghana

Request for reprints to: Dr A. T. Lassey, Department of Obstetrics and Gynaecology, University of Ghana Medical School, P. O. Box GP 4236, Accra, Ghana

\title{
HEPATITIS C VIRUS SEROPREVALENCE AMONG MOTHERS DELIVERING AT THE KORLE-BU TEACHING HOSPITAL, GHANA
}

\author{
A.T. LASSEY, N. K. DAMALE, V. BEKOE and C. A. KLUFIO
}

\begin{abstract}
Objectives: To determine the Hepatitis $\mathrm{C}$ virus (HCV) carrier rate among mothers, and to determine if selected sociodemographic characteristics are associated with $\mathrm{HCV}$ seropositivity.

Design: Maternity Unit of the Korle-Bu Teaching Hospital (KBTH).

Setting: A cross-sectional serological survey of mothers delivering at the KBTH.

Methods: Women who had singleton live births and fresh stillbirths in the two labour wards of the KBTH were randomly selected for screening from $1^{\text {st }}$ March to $30^{\text {th }}$ September, 2001. A structured pre-tested questionnaire was used by trained research assistants to collect and record data on medical and sociodemographic characteristics of the subjects. Maternal blood samples were taken and stored at the Public Health Reference Laboratory. The second generation Murex diagnostics ELISA kit was used to test the maternal sera for HCV antibodies.

Results: Sixteen $(2.5 \%, 95 \%$ CI, 1.5-4.1\%) of the 638 subjects were HCV seropositive. None of the medical and sociodemographic characteristics examined showed any association with HCV seropositivity. No subject or her sexual partner was a drug injector.

Conclusion: The carrier rate of $2.5 \%$ of $\mathrm{HCV}$ infection found in this study is near the top end of the range found in unselected pregnant populations from other parts of the world. Knowing the prevalence rate of $\mathrm{HCV}$ infection in our pregnant population will help policy-makers on the cost effectiveness of available intervention measures.
\end{abstract}

\section{INTRODUCTION}

Hepatitis $\mathrm{C}$ virus (HCV), formerly known as posttransfusion nonA/nonB (NANB) hepatitis virus, is a hepatotrophic virus that is readily transmitted by bloodto-blood contact(1). Illicit use of injected drugs is the principal risk behaviour for the transmission of $\operatorname{HCV}(2,3)$. Its prevalence among drug users exceeds $50 \%(3)$. In countries where blood donors are not routinely screened for $\mathrm{HCV}$, the virus is transmitted through blood transfusion. HCV is therefore an important cause of post-transfusion hepatitis in these countries. $\mathrm{HCV}$ is also transmitted sexually and vertically. The prevailing view is that its sexual spread is less efficient than that of $\operatorname{HIV}(4,5)$. Other modes of transmission include: passage on bloodstained objects such as razor blades used in male circumcision and female genital mutilation and scarification, poor hygiene in tattooing and during body piercing for the purpose of inserting rings and other ornaments. The modes of transmission are therefore similar to those of HIV/AIDS

HCV carrier rates vary from country to country and even in the same country, from region to region. In 1994, during a yellow fever outbreak in the Northern part of Ghana, The Noguchi Memorial Institute for Medical Research tested blood serum samples from suspected yellow fever patients and their close contacts for both yellow fever and hepatitis infection. A seroprevalence rate of $21 \%(18 / 85)$ was found for $\mathrm{HCV}$ infection(6). In a study of 1,300 healthy blood donors at the Korle-Bu Teaching Hospital blood bank, 68 $(5.2 \%)$ of the donors screened positive for $\mathrm{HCV}$ antibodies(7). A similar rate of 5\% was found among normal blood donors in Nigeria(8). HCV infection is very common in Egypt, with $20 \%$ of Egyptians having chronic HCV infection(9). Seroprevalence rates of $0.7 \%-3 \%$ have been found in unselected populations of pregnant women(2,10-12).

The natural history of HCV is highly variable. As in HBV infection, the acute infection may be subclinical, and yet can progress to chronic liver disease. Approximately $50 \%$ of infected patients who are followed for at least 12 months develop biochemical evidence of chronic liver disease. It is estimated that $20 \%$ to $40 \%$ of patients will progress to chronic active hepatitis within five years, and that overall, $20 \%$ to $30 \%$ of infected persons will develop cirrhosis of the liver within 20 to 30 years of infection(4). Ultimately, $75 \%$ 
of viraemic patients will become carriers(4). Once hepatitis $\mathrm{C}$ related cirrhosis has developed the prognosis is bleak with a high incidence of untreatable liver cell cancer and hepatic decompensation leading to an early death. Progression to cirrhosis is most common in those who abuse alcohol(13). For the infected, abstaining from alcohol can reduce progress of the disease.

The Korle-Bu blood bank started screening blood donors for HCV on 1st November 2002.

Because HCV infection can be transmitted vertically, and because of the dire consequences of $\mathrm{HCV}$ infection and because advances in therapy that can cure the mother and prevent vertical transmission are being made, it will be useful to know the HCV prevalence rate in our pregnant population. Further, if HCV seropositivity is strongly associated with selected sociodemographic or medical characteristics of the patients, then these characteristics can be used to select those at risk for serological testing.

The purpose of this study was to determine the HCV carrier rate among parturients at the Maternity Unit of the Korle-Bu Teaching Hospital (KBTH), and to determine if some selected sociodemographic characteristics are associated with HCV seropositivity.

\section{MATERIALS AND METHODS}

The study population consisted of patients who had singleton live-births and fresh stillbirths in the labour wards of the Korle-Bu Teaching Hospital during the study period. Only patients who gave informed consent were included in the study. No patient refused to participate in the study. During the study period, for each day of the week, the principal investigator used a table of random numbers to select 10 numbers out of the numbers 1-30. The randomisation status (Yes or No) of each consecutive number was written on a piece of paper, put in an opaque envelope bearing the consecutive number on the outside of the envelope, and the envelope sealed. Each day, eligible patients were given consecutive numbers, starting from 1, as they were admitted to the labour ward. Each morning, the batch of 30 envelopes for the day was taken to the labour ward and given to the labour ward Sister. After each eligible patient had been given her consecutive number, the Sister opened the respective envelope to see if the patient had been selected for the study or not. Selected subjects were given sequential identification numbers (001-700).

The independent variables investigated are listed in Table 1. A structured pretested questionnaire was used by trained research assistants who were professional midwives to collect and record data on sociodemographic, medical and past reproductive history characteristics of the subjects. The clinical researchers collected data on the index pregnancy, labour, and delivery from the patients' hospital records. The clinical researchers checked the collected data on every subject and corrected any inaccuracies and inconsistencies they found before the subject was discharged from hospital.

After each subject had delivered, the clinical researchers collected a $10 \mathrm{ml}$ blood sample by venepuncture into a heparinised bottle. The sample was sent to the laboratory researcher (VAB) at the Public Health Reference Laboratory where they were stored at $20^{\circ} \mathrm{C}$. The second generation Murex diagnostics ELISA kit was used to test for HCV antibodies. HIV antibodies were screened for by the INNOTEST I and II kit (INNO GENETICS), and confirmed by the INNOLIA-BLOT test (INNO GENETICS).

The clinical researchers transferred the data to computer-coded data collecting forms and punched the data into a computer. The Epi Info version 2000 software was used for the statistical analysis. Association between HCV seropositivity and patient characteristics were examined by the Kruskal-Wallis H-test, Mantel-Haenszel chi-square test, and relative risk, as appropriate. Differences were taken as significant if the P-value was less than 0.05 or the $95 \%$ confidence interval of the relative risk did not include one. From 1st March to 30th September 2001, 638 subjects were enrolled.

\section{RESULTS}

Sixteen $(2.5 \%, 95 \%$ CI $1.5-4.1 \%)$ of the 638 subjects were HCV seropositive. None of the medical conditions and sociodemographic characteristics examined showed any association with HCV seropositivity (Table 1). No subject or her sexual partner was a drug injector. The HIV seroprevalence was $2.7 \%$ (17/638) among these mothers. 
Table 1

Hepatitis $C$ virus positivity by sociodemographic and medical characteristics

\begin{tabular}{|c|c|c|c|c|c|}
\hline \multirow[t]{2}{*}{ Exposure Variable } & & \multicolumn{2}{|c|}{ Hep C Positivity } & \multirow[t]{3}{*}{ Total } & \multirow[t]{2}{*}{ Significance } \\
\hline & & Yes & No & & \\
\hline Married & & No. $(\%)$ & No. $(\%)$ & & No* \\
\hline & Yes & $15(2.4)$ & $613(97.6)$ & 628 & \\
\hline & No & $1(10.0)$ & $9(90.0)$ & 10 & \\
\hline \multirow[t]{3}{*}{ Past Jaundice } & & & & & \multirow[t]{3}{*}{ No* } \\
\hline & Yes & $1 \quad(6.2)$ & $15(93.8)$ & 16 & \\
\hline & No & $14(2.3)$ & $607(97.7)$ & 612 & \\
\hline \multirow[t]{3}{*}{ HIV Positive } & & & & & \multirow[t]{3}{*}{ No* } \\
\hline & Yes & $1 \quad(5.9)$ & $16(94.1)$ & 17 & \\
\hline & No & $15(2.4)$ & $606(97.6)$ & 612 & \\
\hline \multirow[t]{4}{*}{ Nulliparous } & & & & & \\
\hline & Yes & $10(3.0)$ & $318(97.0)$ & 328 & \multirow[t]{3}{*}{ No* } \\
\hline & No & $6 \quad(1.9)$ & $304(98.1)$ & 310 & \\
\hline & Mean parity & $0.88 \pm 1.31$ & $0.99 \pm 1.38$ & 638 & \\
\hline \multirow[t]{3}{*}{ Age $<20$ years } & & & & & \multirow[t]{3}{*}{ No* } \\
\hline & Yes & $4 \quad(5.9)$ & $64(94.1)$ & 68 & \\
\hline & No & $12(2.1)$ & 558(97.9) & 570 & \\
\hline \multirow[t]{3}{*}{ Age $>35$ years } & & & & & \multirow[t]{3}{*}{ No* } \\
\hline & Yes & $1 \quad(1.7)$ & $57 \quad(98.3)$ & 58 & \\
\hline & No & $5 \quad(2.6)$ & $565(97.4)$ & 580 & \\
\hline \multirow[t]{3}{*}{ Schooling } & Mean age & $24.8 \pm 6.54$ & $27.1 \pm 5.98$ & 638 & \multirow{4}{*}{ No* } \\
\hline & Yes & $15(2.5)$ & $593(97.5)$ & 608 & \\
\hline & No & $1 \quad(3.3)$ & $29 \quad(96.7)$ & 30 & \\
\hline \multirow{4}{*}{$\begin{array}{l}\text { Mean number school years } \\
\text { Slum Residence }\end{array}$} & & $6.6 \pm 2.56$ & $7.3 \pm 3.13$ & 638 & \\
\hline & & & & & \multirow{3}{*}{ No* } \\
\hline & Yes & $10(2.2)$ & $444(97.8)$ & 454 & \\
\hline & No & $6 \quad(3.3)$ & $178(96.7)$ & 184 & \\
\hline
\end{tabular}

*Numbers small

\section{DISCUSSION}

The carrier rate of $2.5 \%$ in this study population of parturients at the KBTH is only half the rate found in blood donors at the same hospital(7) and in Nigeria(8); but it is close to the maximum of $3 \%$ in the range $(0.8 \%-3 \%)$ found in populations of non-selected pregnant women from other parts of the world. In a study of 2584 antenatal clinic attendees in Dundee, UK, the prevalence rates of $\mathrm{HCV}$ antibodies among injecting drug users, non-injectors who had a sexual partner who injected, and those with neither risk were $46 \%(6 / 13)$, $14 \%(3 / 21)$, and $0.4 \%(9 / 2550)$ respectively. The relative risk of a female sexual partner of an injector was 35 (95\% Cl 12-101) compared with the sexual partner of a non-injector(2). These findings would suggest that female sexual partners of infected men may be at considerably increased risk of acquiring $\mathrm{HCV}$ sexually. As none of our subjects admitted that she or her partner was a drug injector, we could not examine this association.

HCV may also be passed on through direct mother-to-child-transmission (MTCT)(14). Vertical transmission has been found by polymerase chain reaction in pregnancies complicated by chronic hepatitis $\mathrm{C}$ virus infection $(2,10,17)$. However, the risk has not been conclusively quantified. Some researchers have estimated the in-utero transmission rate of HCV to be between $50 \%$ and $85 \%(15)$ which is higher than that of $\mathrm{HBV}$. On the other hand, other workers have estimated that $5 \%$ to $6 \%$ of anti-hepatitis $\mathrm{C}$ virus positive childbearing women transmit infection to their children in-utero or at the time of delivery(16). Pregnant women who infect their children invariably are viraemic, as demonstrated by the fact that they are PCR-RNApositive for $\mathrm{HCV}$. Combination therapy of thrice a week subcutaneous interferon and twice a day ribavirin produces a sustained clearance of the virus and cure in $40 \%$ of viraemic persons(17). However, $20 \%$ cannot tolerate the side effects of this regimen and withdraw from treatment(18). Recently, a combination of once a week subcutaneous long acting interferons (pegylated interferons) and twice daily oral ribavirin has been found to cure $50 \%$ of infected patients and to be more acceptable to patients(18). Clearance or reduction of viraemia in the last weeks before delivery can be expected to reduce the risk of MTCT, as has been demonstrated for HIV.

Maternal HIV co-infection promotes all three modes of HCV transmission: blood-to-blood contact, sexual intercourse, and mother-to-child transmission (MTCT). The frequency of HCV transmission to sexual 
partners is significantly higher when HIV virus is also transmitted. This would suggest that HIV could be a co-factor for the sexual transmission of $\mathrm{HCV}$ infection(19). HIV infected children are three to four times more likely also to be HCV infected than children without HIV infection(20,21). Higher levels of HCV viraemia in persons with HIV infection may be the explanation for the higher transmission rates in HIV co-infection (19). In the light of these findings, it is important to test all HIV infected women for $\mathrm{HCV}$ infection(19). In this study, the prevalence of HIV infection was $2.7 \%$. There was no statistically significant difference in HCV seroprevalence rates between HIVpositive and HIV-negative subjects.

The small numbers of HIV-positives(17) and HCVpositives(16) may explain the failure to demonstrate any association between the two, and between $\mathrm{HCV}$ seropositivity and the selected sociodemographic factors tested.

In conclusion $\mathrm{HCV}$ infection is a medical condition with grave sequelae for the mother and her child. HCV infection can be spread through blood-to-blood contact, sexually, and by MTCT. As with maternal HIV infection, it may be possible to reduce the risk of MTCT of HCV. Knowing the prevalence rate of $\mathrm{HCV}$ infection in our pregnant population will help policymakers decide on the cost-effectiveness of available intervention measures. The carrier rate of $2.5 \%$ found in this study is near the top end of the range found in unselected pregnant populations from other parts of the world.

\section{ACKNOWLEDGEMENTS}

We wish to thank the patients for consenting to participate in this study and also the laboratory staff for their invaluable contribution.

\section{REFERENCES}

1. Tibbs, C. Methods of transmission of hepatitis C. Viral Hepatitits. 1995; 2:113-120.

2. Goldberg, D., McIntyre, P.G., Smith, R., et al. Hepatitis $\mathrm{C}$ virus among high and low risk pregnant women in Dundee: unlinked anonymous testing. Brit. J. Obstet. Gynaecol. 2000; 108:365-370

3. Wodak, A. and Crofts, N. Once more into the breach: controlling hepatitis $\mathrm{C}$ in injecting drug users. Addiction. 1996; 91:181-184.

4. Centers for Disease Control and Prevention. Recommendations for the Prevention and Control of Hepatitis C Virus (HCV) Infection and HCV-Related Chronic Disease. Morbd. Mort. Wkly Ret. 1998; 47(No. RR019pp).

5. Wyld, R., Robertson, J.R., Brettle, R.P., et al. Absence of hepatitis $\mathrm{C}$ transmission but frequent transmission of HIV- 1 from sexual contacts of doubly infected individuals. $J$ lnfect. 1997; 35:163-166.

6. Ministry of Health, Ghana, Report on Yellow Fever Outbreak, 1994.

7. Acquaye, J.K., and Tettey-Donkor, D. Frequency of hepatitis $\mathrm{C}$ virus antibodies and elevated serum transaminase levels in Ghanaian blood donors. West Afr. J. Med. 2000; 19: 239-241

8. Adewuyi, J.O. Prevalence of antibodies to hepatitis $\mathrm{C}$ virus among normal blood donors and multitransfused sickle cell anaemia patients in Nigeria. Trop. Doctor. 1996; 26:29-30

9. Foster, G. London -A hot bed of hepatitis. Capital Doctor 2002; 14:30-31.

10. MacLean, A.B., Cameron, S. and Follett, E.A.C. Prevalence of hepatitis $\mathrm{B}$ and $\mathrm{C}$ viruses and human immunodeficiency virus infection in women of reproductive age. Brit. J. Obstet. Gynaecol. 1993; 100:702-703.

11. Ward, C., Tudor-Williams, G., Cotzias, T., et al. Prevalence of hepatitis $\mathrm{C}$ among pregnant women attending an inner London obstetric department: uptake and acceptability of named antenatal testing. Gut. 2000; 47:277-280.

12. Lima, M.P.J.S., Pedro, R.J. and Rocha, M.D.C. Prevalence and risk factors for hepatitis $\mathrm{C}$ virus (HepCV) infection among pregnant Brazilian women. Intern. J. Gynecol. Obstet. 2000; 70:319-326.

13. Poynard, T., Bedossa, P. and Opolon, P. Natural history of liver fibrosis progression in patients with chronic hepatitis. Lancet. 1997; 349:825-832.

14. Terrault, N.A. Epidemiological evidence for perinatal transmission of hepatitis C virus. Viral Hep Rev. 1998; 4:245-258

15. Tanzi, M., Bellelli, E., Benaglia, C., et al. The prevalence of hepatitis $\mathrm{C}$ virus infection in a cohort of pregnant women, the related risk factors and the possibility of vertical transmission. Eur. J. Epid. 1997; 13:517-521

16. Gray, J.J., Geraghty, B., and Desselberger, U. Algorithms for HCV antibody testing. PHLS Microbiol Digest. 1994; 10:182-189.

17. Davis, G., Esteban-Muir, R., Rustgi V., et al. Recombinant interferon alfa- $2 \mathrm{~b}$ alone or in combination with ribavirin for treatment of relapse of chronic hepatitis C. New. Engl. J. Med. 1998; 339:493-499.

18. Hitchen, L. Study reveals effectiveness of early action in hepatitis C. Hosp. Doctor 2003;Reed Bus. Info.Healthcare:6.

19. European Paediatric Hepatitis C Virus Network (Pembrey L, Newell M-L, Tovo (P-A) Effects of mode of delivery and infant feeding on the risk of mother-to-child transmission of hepatitis C virus. Brit. J. Obstet. Gynae. 2001; 108: 371-377.

20. Thomas, S., Newell, M.L., Peckam, C.S., Ades, A., and Hall, A. A review of hepatitis C virus (HCV) vertical transmission: risks of transmission to infants born to mothers with and without $\mathrm{HCV}$ viraemia or human immunodeficiency virus infection. Int. J. Epidem. 1998; 27:108-117.

21. Papaevangelou, V., Pollack, H., Rochford, G., et al. Increased transmission of vertical hepatitis $\mathrm{C}$ virus (HCV) infection to human immunodeficiency virus (HIV)-infected infants of HIV-and HCV -co-infected women. J. Infect. Dis. 1998; 178:1047-1052. 